\author{
Lähteet \\ Niskanen, Ninna - Mäntynen, Anne \\ 2012: Virittäjän lukijakyselyn tuloksia. \\ - Virittäjä 116 s. 125-131. \\ SATOKANGAS, Henri 2018: Uskonnon \\ oppikirjojen moniäänistymiskehitys ja \\ muuttuva ryhmäkonstruointi. - Virittäjä \\ 122 s. $112-121$.
}

TuUkanov, Maija 2016: Kielet kerroksittain - suomen kielen ja suomalaisen viittomakielen simultaania yhteistyötä keskustelussa. - Virittäjä 120 s. 583-594.

Vierula, Suvi 2017: Kanssa, kans ja kaa - postposition muutoksen tarkastelua. - Virittäjä 121 s. 265-275. https://doi. org/10.23982/vir.61037.

\title{
Kielenvälityksestä arkikeskusteluissa
}

\author{
Katariina Harjunpää: Translatory prac- \\ tices in everyday conversation. Bilingual \\ mediating in Finnish-Brazilian Portuguese \\ interaction. Helsinki: Helsingin yliopisto \\ 2017. 308 s. ISBN 978-951-51-3226-0.
}

Katariina Harjunpää tutkii monografiaväitöskirjassaan sitä, miten maallikkokääntäminen jäsentyy vuorovaikutuksellisesti monikielisissä arkikeskusteluissa. Tutkimusaineisto muodostuu erilaisissa ateriointi- ja muissa seurustelutilanteissa tuttavien ja perheenjäsenten kesken käydyistä keskusteluista. Osanottajien kielelliset repertoaarit ovat epäsymmetriset: osa on yksikielisiä ja osa enemmän tai vähemmän kaksikielisiä. Pääaineisto, laajuudeltaan noin yhdeksän tuntia, käsittää neljä videotallennetta, joista kolme on kuvattu Brasialiassa ja yksi Suomessa. Keskustelun kielinä ovat suomi ja brasilianportugali, toisinaan myös englanti lingua francana. Metodologisesti tutkimus edustaa multimodaalista keskustelunanalyysia. Työn keskiössä ovat vuorot, joissa vaihdetaan keskustelun kieltä ja jotka ovat tulkittavissa aiemman puheen välitykseksi toisille keskustelun osanottajille. Teok- sessa on johdannon ja tutkimusongelmaa taustoittavan luvun lisäksi neljä analyysilukua sekä pohdinta- ja johtopäätösosuus.

\section{Tutkimusongelmat}

Kääntämistä ja tulkkausta, jotka kuuluvat ilmiöinä monikieliseen vuorovaikutukseen, esiintyy niin arki- kuin institutionaalisissa keskusteluissa. Harjunpää lähtee tutkimusongelmansa muotoilussa liikkeelle tästä keskustelunanalyyttisesta erottelusta kahden keskustelutyypin välillä. Empiirisenä, aineistosta nousevana lähtökohtana on, että arkikeskusteluissa kääntäminen (tai tulkkaus) ei ole systemaattista vaan sitä esiintyy vain paikoitellen. Ammatillisesta kääntämisestä poiketen maallikkokääntäjällä ei ole ennalta määrättyä kääntäjän roolia, vaan hän on keskustelussa mukana yhdenvertaisena osanottajana muiden joukossa. Kielenvälityksen ${ }^{1}$ tarve syntyy monikielisissä

1. Ammattikääntämisen ja -tulkkauksen ulkopuolisia kääntämisen ja tulkkauksen ilmiöitä koskevasta terminologiasta ks. myös Pilke, Kolehmainen \& Penttilä 2015. 
arkikeskusteluissa endogeenisesti, ilman institutionaalisia puitteita. Näistä lähtökohdista Harjunpää muotoilee ensimmäisen tutkimusongelmansa: mitkä vuorovaikutukselliset seikat johtavat kääntämiseen jollakin tietyllä keskustelun hetkellä?

Käännösvuoroja ja maallikkokääntäjän roolia voi lähestyä tarkastelemalla ensinnäkin sitä, miten diskursiivinen toimijuus (discursive agency), eli sellaiset seikat kuten kielellisen toiminnan tuottaminen, kontrolloiminen ja siihen sitoutuminen, jakautuvat alkuperäisen ja välittäjänä toimivan puhujan välillä. Vuorovaikutuksen jäsentymistä ajatellen taas voi kysyä, miten käännöspuhe on tunnistettavissa ja erotettavissa muusta koodinvaihdosta; se, että kaksikielinen puhuja vaihtaa keskustelun kieltä, ei vielä riitä sen merkiksi, että puhe olisi välittävässä suhteessa aiempaan erikieliseen puheeseen. Harjunpään toisena tutkimusongelmana onkin, millä kielellisillä keinoilla välittävä puhuja osoittaa puheensa kantavan aiemman puhujan ääntä.

Käännösvuorojen kielellisten piirteiden analyysissa tutkimus tukeutuu vuorovaikutuslingvistiikkaan, jossa kielioppi nähdään sosiaalisen vuorovaikutuksen muovaamana ja sen haasteisiin vastaavana dynaamisena resurssina (ks. esim. Selting \& Couper-Kuhlen toim. 2001). Harjunpään tutkimuksen tavoitteena on edellisten kysymysten lisäksi selvittää sitä, millaisia toimintoja käännösvuorot toteuttavat suhteessa edeltävään välitettävään puheeseen ja miten käännösvuorojen muotoilu heijastaa ja muokkaa niiden vuorovaikutuksellista kontekstia.

\section{Analyysi}

Väitöskirjan analyysiosa alkaa luvusta 3. Luvussa tarkastellaan käännösvuoroja, joissa on jokin leksikaalinen tai kieliopillinen merkintä siitä, että ne referoivat aiempaa puhetta. Eksplisiittisin tapa merkitä käännösvuoro referoinniksi on kehystää se johtolauseella (esim. niin Gaia sano että- $-^{2}$, s. 73). Vuorovaikutusasetelmiltaan johtolauseelliset käännösvuorot osoittautuvat kuitenkin kompleksisiksi: niitä käytetään tilanteissa, joissa kääntämistä motivoi jokin muukin seikka kuin pelkästään kielellisen sisällön välitys erikieliselle osanottajalle. Ne esiintyvät usein muutaman vuoron päässä niiden lähteenä olevasta puheesta. Keskustelun rakenteen näkökulmasta johtolauseen avulla voidaan luoda sekventiaalinen tila käännösvuorolle, joka ei sovi suoraan, ilman kehystystä, välittömästi edeltävän vuoron jatkoksi. Toisaalta diskursiivisen toimijuuden näkökulmasta johtolauseen käyttöön liittyy välittävän puhujan arviointia siitä, mikä aiemmassa puheessa ja toiminnassa on sisällöllisesti relevanttia erikielisen osanottajan kannalta ja miten käännös voidaan tuottaa hänelle ymmärrettävässä ja sosiaalisesti sopivassa muodossa. Tässä mielessä johtolause luo etäisyyttä välittävän puhujan ja aiemman puheen välille.

Muita Harjunpään tarkastelemia referoinnin osoittamisen keinoja ovat puheenaiheen nimeämiset, asenteellisesta puheesta tehdyt yleistykset, vuoronalkuiset partikkelit että ja que sekä logoforisiksi tulkittavat kolmannen persoonan viittaukset käännettävään puhujaan. Kieltä vaihtavat puheenaiheen nimeämiset (esim. (a) gente tá falamo da cultura de sauna 'we are talking about sauna culture', s. 82) esiintyvät yhteyksissä, joissa vuoron vastaanottaja ei ole ollut mukana aiemmassa keskustelussa. Käännösvuoron muotoilu implikoi puheenaiheen ryhmäsidonnaisuutta ja toimii perusteluna kielivalinnalle. Aiempaa puhetta voidaan tehdä ymmärrettäväksi erikieliselle osanottajalle myös sellaisilla yleistävillä luonnehdinnoilla kuin tääl kerrotaan paljo portugalilaisista vitsejä (s. 97). Kielenvälitystä motivoi tällöin aiemman keskustelun affektinen sävy, joka on havaittavissa kielestä riippumattomasti, esimerkiksi keskusteluun liittyvästä naurusta.

2. Litteraatteja on yksinkertaistettu. 
Implisiittisempi merkki referoinnista ovat vuoronalkuiset partikkelit että ja que (että-partikkelista ks. esim. Koivisto, Laury \& Seppänen 2011). Ne sitovat kieltä vaihtavan lausuman edeltävään puheeseen ja merkitsevät sen selittämisen kohteeksi (esim. et että suames eiku siis ranskassa tää on kans cou ku suomessa se on se taivaankappale, s. 115-116). Partikkelialkuisia selittäviä käännösvuoroja esiintyy esimerkiksi tilanteissa, joissa jonkun osanottajan epäkoherentti toiminta paljastaa, ettei hän ole riittävästi ymmärtänyt tai seurannut aiempaa puhetta. Silloin taas, kun käännettävänä on yhden osallistujan itseä koskeva puhe, referointia voi käännöspuheessa osoittaa suomen logoforinen hän-pronomini (ks. Laitinen 2005) ilman muita kehystäviä aineksia (esim. hän soitti rumpuja aikoinaan kovasti, s. 120). Harjunpää tarkastelee myös portugalin ele- ja ela-pronominien vastaavanlaista käyttöä.

Luvussa 4 siirrytään käsittelemään vuoroja, joissa ei ole referointia osoittavia kielellisiä aineksia mutta joiden sisäinen rakenne ohjaa niiden tulkintaa käännösvuoroiksi. Harjunpään huomio on kiinnittynyt siihen, että käännösvuorot alkavat usein leksikaalisesti raskaalla nominilausekkeella. Hän kutsuu tällaisia NP:itä vuoronalkuisiksi avainsanoiksi (turninitial keywords): ne poimivat aiemmasta erikielisestä puheesta välitettäväksi jonkin keskeisen sisällöllisen aineksen. Harjunpää esittää, että vuoronalkuisella leksikaalisella aineksella on itsessään rakenteellinen potentiaali osoittaa sidosta aiempaan puheeseen. Tukea ajatukselle antavat vuorovaikutuslingvistiset tutkimukset, joissa vuoronalkuisten lohkeamalausekkeiden on todettu nostavan esiin referenttejä - olivatpa ne uusia tai jo aiemmin puheena olleita - siten, että ne asettuvat jo olemassa olevaan diskursiiviseen kehykseen (ks. esim. Etelämäki 2006: 86).

Avainsanalla alkavissa käännösvuoroissa on toiminnallisesti kyse aiemman kerto- muksen tai selittävän puheen uudelleenkerronnasta (retelling). Harjunpää erottelee neljä tapaustyyppiä sen mukaan, millainen vuoro tai vuorottelu vuoronalkuisesta leksikaalisesta aineksesta lähtien muodostuu. Ensimmäisessä tyypissä avainsanailmausta seuraa tauko, joka tarjoaa vastaanottajalle tilaisuuden reagoida, esimerkiksi nyökkäämällä. Käännösvuoron segmentoinnin avulla luodaan siis uudelleenkerronnalle tunnistettava alku yhdessä vastaanottajan kanssa. Toisessa tyypissä alkuasemainen, syntaktisesti erillinen avainsanailmaus ja sitä seuraava rakenneyksikkö tuotetaan saumattomasti yhtenä prosodisena kokonaisuutena. Avainsanailmaus poimii aiemmasta puheesta jonkin referentin, joka ei kuitenkaan ole käännöspuheen puheenaihe vaan toimii siltana varsinaiseen asiaan siirtymiselle.

Kolmannessa tyypissä alkuasemainen NP on sekä syntaktisesti että prosodisesti integroitu yksiosaisen käännösvuoron rakenteeseen. Avainsanailmaus voi olla etualaistettu kahdessa mielessä: se sijaitsee finiittiverbin (ja subjektin) edellä sanajärjestykseltään tunnusmerkkisessä käännöslausumassa (mutta marjametsästä sä tiedät enemmän, s. 173) ja lisäksi se vastaa edeltävässä erikielisessä vuorossa verbinjälkeisenä esiintynyttä ilmausta ( $\operatorname{sim}$ ele sabe mais sobre frutinha 'yes he knows more about berries', mp.). Käännettävän puheen ja käännösvuoron puhuja on tyypillisesti sama henkilö, joka osoittaa erikieliset, vuorovaikutuksellisesti eri lailla suuntautuneet vuoronsa eri vastaanottajille. Viimeisenä tyyppinä Harjunpää käsittelee itsenäisiä, yksin vuoron muodostavia NP:itä, jotka välittävät aiemmasta puheesta vain yhden keskeisen seikan.

Luvussa 5 Harjunpää täydentää kuvaa käännösvuorojen muotoilusta analysoimalla tapauksia, joissa ei ole mitään erityisiä rakenteellisia, käännöstulkintaan ohjaavia piirteitä. Tällaisia vuoroja käytetään muun muassa kommentoimaan toimintoja tai asioita, jotka sijoittuvat fyysi- 
sesti vuorovaikutustilanteen osanottajien näkökenttään tai ovat meneillään olevan monikielisen keskustelun perusteella heidän yhteisen huomionsa kohteena. Tyypillistä näille tilanteille on, että puhuja kääntää omaa toisenkielistä puhettaan tai että hänellä on puheenaiheeseen muusta syystä episteeminen pääsy, jonka turvin hän voi välittää aiempaa puhetta omasta näkökulmastaan ja vuoron sisältöön henkilökohtaisesti sitoutuen.

Tutkielman empiirinen osuus päättyy lukuun 6 , jossa tarkastellaan kielestä toiseen välittämistä rajallisessa, kysymysten ja vastausten muodostamassa sekventiaalisessa ympäristössä. Selvitettävänä on, miten kysymysvuoron sekventiaalinen projektio eli odotus tietynlaisesta vastauksesta välitetään erikieliselle puhujalle, millaisen puhujakollektiivin kysymyksen alkuperäinen esittäjä ja välittävä puhuja muodostavat keskenään ja miten diskursiivisen toimijuuden jakautuminen näkyy käännösvuoroissa. Lisäksi havainnoidaan sitä, miten aiemman toiminnan muokkaus (esim. kysymystyypin vaihto) käännösvuorossa vaikuttaa vuorovaikutuksen lopputulemaan ja missä muodossa erikielisen puhujan vastaus välitetään alkuperäiselle puhujalle.

Analyysiluvut luovat monipuolisen kuvan arkikeskustelujen käännösvuorojen kielellisistä piirteistä. Lisäksi niistä välittyy paljon tietoa siitä, millaisissa keskustelutilanteissa kielenvälitystä tapahtuu ja millaisia vuorovaikutussekvenssejä käännösvuorojen ympärille syntyy. Väitöskirjan päätösluku tarjoaa ytimekkään koosteen analyysien päätuloksista. Kiinnostavaa on esimerkiksi se, että Harjunpään aineistossa erikielinen puhuja, jolle käännösvuoro suunnataan, ei yleensä ole suoranaisesti osallistunut aiempaan, käännöksen lähteenä olevaan keskusteluun. Arkikeskusteluissa kielenvälitykseen liittyykin aina multimodaalista neuvottelua osallistujuudesta. Kääntäminen vastaa muutoksiin osallistumis- kehikossa - esimerkiksi siihen, että erikielinen osallistuja on osoittanut kehollisesti kiinnostusta keskusteluun, johon hänellä ei ole kielellistä pääsyä. Kielenvälitystä motivoi myös välittävän puhujan arvio jonkin puhejakson senhetkisestä relevanssista erikieliselle puhujalle - esimerkiksi silloin, kun aiempi puhe koskee ensisijaisesti erikielisen puhujan tiedollista aluetta.

\section{Lopuksi}

Harjunpään tutkimus herättää pohtimaan, mistä kääntämisessä lopulta on kysymys, kun sitä tarkastellaan vuorovaikutuksessa endogeenisesti, ilman institutionaalisia puitteita ilmenevänä sosiaalisena toimintana. Työn ensimmäisistä esimerkkianalyyseistä lähtien käy selväksi, että kielenvälitysvuorot eivät ole aiemman puheen sanasanaisia käännöksiä. Itse asiassa arkinen kielenvälitys on jo vuorovaikutuksellisilta lähtökohdiltaan sellaista, ettei ajatus tarkan toisenkielisen vastineen tuottamisesta ole edes mielekäs. Välityksen tai ymmärrettäväksi tekemisen kohteena on aiempi tai meneillään oleva sosiaalinen toiminta, ei pelkkä aiemman puheen kielellinen sisältö.

Harjunpää käyttää puhujan keinoista välittää aiempaa puhetta ja toimintaa nimitystä translatoriset käytänteet. Avoimeksi jää, missä kulkevat tutkitun ilmiön rajat. Voi myös kysyä, muodostaako tarkasteltujen tapausten kirjo yhtenäisen ilmiön vai onko kyse toisiinsa eri tavoin limittyvien ilmiöiden verkostosta. Kuten Harjunpää itsekin toteaa, monissa esimerkeissä ollaan varsin kaukana siitä, mitä jossakin toisessa teoreettisessa viitekehyksessä pidettäisiin kääntämisenä (s. 20). Erilaisista kääntämisen määritelmistä nousee keskeiseksi piirteeksi se, että käännöksellä tulee olla jonkinlainen lähde aiemmassa puheessa. Ilmiöt eivät koske vain kaksikielistä vuorovaikutusta, vaan myös yksikielisessä keskustelussa vuoroja 
kierrätetään ja lausumilla on substraatteja (termistä ks. Goodwin 2013) aiemmassa puheessa. Osa Harjunpään analysoimista tilanteista on sellaisia, että vastaavanlaista aiemman puheen välitystä tai selittämistä voi hyvin kuvitella esiintyvän myös yksikielisissä monenkeskisissä keskusteluissa, joissa kaikilla osallistujilla ei ole samanlaista pääsyä keskusteluun tai sen aiheisiin.

Harjunpään teoksen merkitys ei näin rajoitu vain kääntämisen problematiikkaan, vaan se ulottuu myös yleisemmälle tasolle. Monikielisten arkikeskustelujen tutkiminen avaa kiinnostavia näkymiä vuorovaikutuksen reaaliaikaisen eksplikoinnin ilmiöihin, jotka kuuluvat yhtä lailla yksikielisiin keskusteluihin mutta joita ei voi niistä samalla lailla problematisoida, koska vuorovaikutuksen kielelliset keinot ovat jaetut.

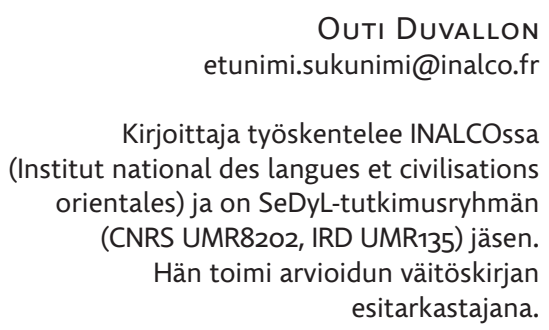

\section{Väitöstutkimus toimijuudesta toisella kielellä}

\begin{abstract}
Aija Virtanen: Toimijuutta toisella kielellä. Kansainvälisten sairaanhoitajaopiskelijoiden ammatillinen suomen kielen taito ja sen kehittyminen työharjoittelussa. Jyväskylä Studies in Humanities 311. Jyväskylä: Jyväskylän yliopisto 2017. Johdanto 137 s., artikkelit 97 s. ISBN 978-951-39-7021-5.
\end{abstract}

Suomea voi nykyään pitää erittäin monimuotoisena yhteiskuntana, jossa asuu ih-

\section{Lähteet}

ETELÄMÄKI, MARJA 2006: Toiminta ja tarkoite. Tutkimus suomen pronominista tämä. Helsinki: Suomalaisen Kirjallisuuden Seura.

Goodwin, Charles 2013: The co-operative, transformative organization of human action and knowledge. - Journal of Pragmatics 46 s. 8-23.

Koivisto, Aino - Laury, Ritva - SepPÄnen, Eeva-LeEna 2011: Syntactic and actional characteristics of Finnish että-clauses. - Ritva Laury \& Ryoko Suzuki (toim.), Subordination in conversation. A cross-linguistic perspective s. 69-102. Amsterdam: John Benjamins.

Laitinen, LeA 2005: Hän, the third speech act pronoun in Finnish. - Ritva Laury (toim.), Minimal reference. The use of pronouns in Finnish and Estonian discourse s. 75-106. Helsinki: Suomalaisen Kirjallisuuden Seura.

Pilke, Nina - Kolehmainen, Leena - Penttilä, EsA 2015: Luonnollinen kääntäminen, kielenvälitys vai ad-hoc -tulkkaus? Terminologinen näkökulma käännöstieteen reuna-alueille. - Virittäjä 119 s. 318-341.

Selting, Margaret - Couper-Kuhlen, Elizabeth (toim.) 2001: Studies in interactional linguistics. Amsterdam: John Benjamins. misiä 177:stä eri maasta (Suomen virallinen tilasto 2017). Yhteiskunnan monimuotoistumista tutkitaan useilla tieteenaloilla ja yhä enemmän myös suomen kielen alalla. Aija Virtasen väitöskirja liittyy tähän muotoutumassa olevaan tutkimusperinteeseen keskittymällä työperäistä maahanmuuttoa ja ammatissa vaadittavaa kielitaitoa koskevaan problematiikkaan. Virtasen tutkimus on valmistunut osana laajempaa 